\title{
Potential chimeric peptides to block the SARS-CoV-2 spike
}

\section{receptor-binding domain [version 1; peer review: 2 approved,}

\section{1 approved with reservations]}

\author{
Debmalya Barh (iD)* , Sandeep Tiwari2*, Bruno Silva Andrade (iD)3, \\ Marta Giovanetti2,4, Eduardo Almeida Costa (iD) 5, Ranjith Kumavath (iD6, \\ Preetam Ghosh7, Aristóteles Góes-Neto (D8, Luiz Carlos Junior Alcantara2,4, \\ Vasco Azevedo 2
}

\footnotetext{
${ }^{1}$ Centre for Genomics and Applied Gene Technology, Institute of Integrative Omics and Applied Biotechnology (IIOAB), Nonakuri, Purba Medinipur, WB, India

2Laboratório de Genética Celular e Molecular, Departamento de Biologia Geral, Instituto de Ciências Biológicas, Universidade Federal de Minas Gerais (UFMG), Belo Horizonte, Minas Gerais, Brazil

3Laboratório de Bioinformática e Química Computacional, Departamento de Ciências Biológicas, Universidade Estadual do Sudoeste da Bahia (UESB), Jequié, Bahia, Brazil

4Laboratório de Flavivírus, Instituto Oswaldo Cruz, Fundação Oswaldo Cruz, Rio de Janeiro, Brazil

${ }^{5}$ Núcleo de Biologia Computacional e Gestão de Informações Biotecnológicas (NBCGIB), Universidade Estadual de Santa Cruz (UESC), Km 16, Salobrinho, Ilhéus, Bahia, CEP 45662-900, Brazil

${ }^{6}$ Department of Genomic Science, School of Biological Sciences, University of Kerala, Tejaswini Hills, Periya P.O, Kasaragod, Kerala, 671316, India

${ }^{7}$ Department of Computer Science, Virginia Commonwealth University, Richmond, VA, 23284, USA

${ }^{8}$ Laboratório de Biologia Molecular e Computacional de Fungos, Departamento de Microbiologia, Instituto de Ciências Biológicas, Universidade Federal de Minas Gerais (UFMG), Belo Horizonte, Minas Gerais, Brazil
}

* Equal contributors

V1 First published: 09 Jun 2020, 9:576

https://doi.org/10.12688/f1000research.24074.1

Latest published: 09 Jun 2020, 9:576

https://doi.org/10.12688/f1000research.24074.1

\section{Abstract}

Background: There are no known medicines or vaccines to control the COVID-19 pandemic caused by SARS-CoV-2 (nCoV). Antiviral peptides are superior to conventional drugs and may also be effective against COVID-19. Hence, we investigated the SARS-CoV-2 Spike receptor-binding domain (nCoV-RBD) that interacts with hACE2 for viral attachment and entry.

Methods: Three strategies and bioinformatics approaches were employed to design potential nCoV-RBD - hACE2 interaction-blocking peptides that may restrict viral attachment and entry. Firstly, the key residues interacting with nCoV-RBD - hACE2 are identified and hACE2 sequence-based peptides are designed. Second, peptides from five antibacterial peptide databases that block nCoV-RBD are identified; finally, a chimeric peptide design approach is used to design peptides that can bind to key nCoV-RBD residues. The final peptides are

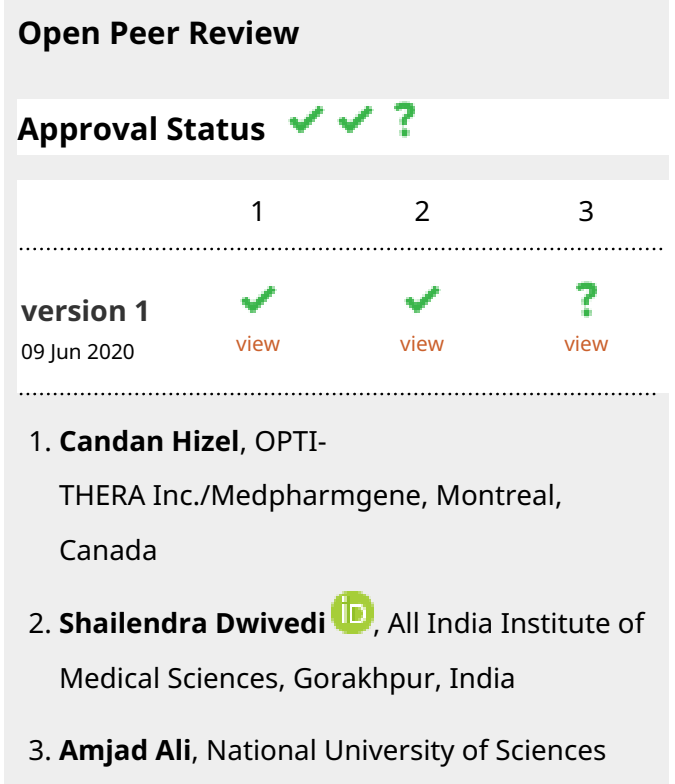


selected based on their physiochemical properties, numbers and positions of key residues binding, binding energy, and antiviral properties.

Results: We found that: (i) three amino acid stretches in hACE2 interact with nCoV-RBD; (ii) effective peptides must bind to three key positions of nCoV-RBD (Gly485/Phe486/Asn487, Gln493, and Gln498/Thr500/Asn501); (iii) Phe486, Gln493, and Asn501 are critical residues; (iv) AC20 and AC23 derived from hACE2 may block two key critical positions; (iv) DBP6 identified from databases can block the three sites of the nCoV-RBD and interacts with one critical position, Gln498; (v) seven chimeric peptides were considered promising, among which cnCoVP-3, cnCoVP-4, and cnCoVP-7 are the top three; and (vi) cnCoVP-4 meets all the criteria and is the best peptide.

Conclusions: To conclude, using three different bioinformatics approaches, we identified 17 peptides that can potentially bind to the nCoV-RBD that interacts with hACE2. Binding these peptides to nCoVRBD may potentially inhibit the virus to access hACE2 and thereby may prevent the infection. Out of 17,10 peptides have promising potential and need further experimental validation.

Keywords

Antiviral peptides, COVID-19, SARS-CoV-2, nCoV-19, peptide design, ACE2, Spike protein and Technology (NUST), Islamabad, Pakistan

Any reports and responses or comments on the article can be found at the end of the article.

This article is included in the Emerging Diseases and Outbreaks gateway.

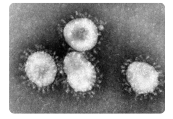

This article is included in the Coronavirus

collection.

Corresponding author: Debmalya Barh (dr.barh@gmail.com)

Author roles: Barh D: Conceptualization, Data Curation, Formal Analysis, Investigation, Methodology, Writing - Original Draft Preparation, Writing - Review \& Editing; Tiwari S: Data Curation, Formal Analysis, Software, Validation; Silva Andrade B: Formal Analysis; Giovanetti M: Formal Analysis; Almeida Costa E: Formal Analysis; Kumavath R: Formal Analysis; Ghosh P: Formal Analysis, Writing Review \& Editing; Góes-Neto A: Formal Analysis, Writing - Review \& Editing; Carlos Junior Alcantara L: Formal Analysis; Azevedo V: Project Administration, Validation, Writing - Review \& Editing

Competing interests: No competing interests were disclosed.

Grant information: ST is supported by Coordenação de Aperfeiçoamento de Pessoal de Nível Superior, Brasil (CAPES) and MG is supported by Fundação de Amparo à Pesquisa do Estado do Rio de Janeiro (FAPERJ).

The funders had no role in study design, data collection and analysis, decision to publish, or preparation of the manuscript.

Copyright: ( 2020 Barh D et al. This is an open access article distributed under the terms of the Creative Commons Attribution License, which permits unrestricted use, distribution, and reproduction in any medium, provided the original work is properly cited.

How to cite this article: Barh D, Tiwari S, Silva Andrade B et al. Potential chimeric peptides to block the SARS-CoV-2 spike receptorbinding domain [version 1; peer review: 2 approved, 1 approved with reservations] F1000Research 2020, 9:576 https://doi.org/10.12688/f1000research.24074.1

First published: 09 Jun 2020, 9:576 https://doi.org/10.12688/f1000research.24074.1 


\section{Introduction}

The world is currently experiencing the severe coronavirus disease 2019 (COVID-19) pandemic caused by SARS-CoV-2 or novel corona virus $(\mathrm{nCoV})$ that originated from the Wuhan city, China ${ }^{1,2}$, and spread across the world. So far, two million people have been infected and more than 120,000 deaths are recorded across the globe. The death rate is $3-20 \%$ depending on the countries and the most affected countries are the USA, Italy, Spain, the UK and France, which have each recorded more than 10,000 deaths within a couple of weeks (WHO COVID-2019 situation reports). SARS-CoV-2 is highly contagious in humans and so far no medicine or vaccine has been developed to tackle the virus, making it impossible to control its spread across the globe ${ }^{3}$. Although drugs like hydroxychloroquine, remdesivir, and lopinavir ${ }^{4}$ are currently being suggested to treat COVID-19 infection, there is no clinical study so far to prove their efficacy in treating these patients. Therefore, currently there is a global search for appropriate drug and vaccine candidates against SARS-CoV-2.

SARS-CoV-2 has shown $80 \%$ genome identity with SARS$\mathrm{CoV}$, which is the causal agent of severe acute respiratory syndrome (SARS) seen in 2002-20035. SARS-CoV binds to the human angiotensin-converting enzyme 2 (hACE2) receptor through its Spike protein (S) to enter into the host cell ${ }^{6}$, and it is now reported that SARS-CoV-2 also binds to ACE2 to transmit its genetic material to human cells ${ }^{7-9}$. Therefore, blocking the Spike protein of SARS-CoV-2 could be an attractive and effective way to prevent the SARS-CoV-2 infection.

The crystal structure of the hACE2 receptor and the receptor binding domain (RBD) of the SARS-CoV-2 Spike protein (nCoV-RBD) (PDB: 6M17>) showed that a total of eight residues, namely, Gln24, Asp30, His34, Tyr41, Gln42 in $\alpha 1$ helix, Met82 in $\alpha 2$ helix, and Lys353 and Arg357 in the $\beta 3$ and $\beta 4$ linkers, are important for the binding 9 . The important interactions between the nCoV-RBD with ACE2 are Lys417 (Spike) --Asp30 (hACE2), Tyr453 (Spike) --His34 (hACE2), Gln474 (Spike) --Gln24 (hACE2), Phe486 (Spike) --Met82 (hACE2), Gln498 (Spike) --Tyr41 (hACE2), Thr500 (Spike) --Gln42 (hACE2), and Asn501 (Spike) --Lys3539 .

Peptide-based drugs are a better choice than conventional drugs due to their higher efficiency, lesser molecular weight, and lower toxicity and side effects ${ }^{10}$. In this regard, antiviral peptides (AVPs), and a subset of antimicrobial peptides (AMPs), are of specific interest due to their higher efficacy in inhibiting viral infection by targeting various stages of the viral life cycle. AVPs can directly invoke innate immune response ${ }^{11}$ and inhibit viral entry by targeting viral attachment and entry to host cell, and replication, transcription, translation, multiplication, and release inside the host cell ${ }^{12,13}$. Previously, several AVPs have been reported to inhibit the SARS-CoV Spike protein or viral entry ${ }^{14-16}$.

In this report, using bioinformatics strategies, we attempted to design anti-Spike peptides for SARS-CoV-2 towards motivating potential therapeutics against the SARS-CoV-2 infection.

\section{Methods}

We adopted three strategies to predict potential AVPs against the SARS-CoV-2 Spike protein.

\section{Strategy I}

In the first strategy, we re-analysed the SARS-CoV-2 Spike RBD with hACE2 to identify the key interacting residues in both the proteins. A recent report suggests that the $\mathrm{B}$ chain of SARS-CoV-2 Spike protein interacts with the B or D homodomain of hACE2 ${ }^{9}$. Therefore, in this analysis, we used the individual B chain of SARS-CoV-2 Spike RBD (PDB: 6LZG) and the B chain of hACE2 (PDB: 6M18) to dock with each other using the HADDOCK 2.2 server $^{17}$, providing active residues of both the proteins as described by Yan et al., (2020) ${ }^{9}$ and using default parameters. Based on the binding interactions and based on previous reports ${ }^{9}$, we identified the key interacting residues. In the next step, we designed a number of AVPs based on the interacting hACE2 residues to the RBD of the Spike protein. To design the AVPs, we used simple permutation and combination approach of amino acids, keeping the key interacting amino acids and their positions fixed in the peptide. Binding to SARS-CoV-2 Spike RBD with the designed AVPs was determined by the HPEPDOCK protein-peptide docking $\operatorname{server}^{18}$. For the HPEPDOCK analysis, we used the SARS-CoV-2 Spike RBD (PDB: 6LZG) B chain and the sequence of the peptides in FASTA format, specifying eight binding sites (Lys417, Tyr453, Gln474, Phe486, Gln493, Gln498, Thr500, and Asn501) of Spike-RBD ${ }^{9}$ and 100 peptide binding mode. The final peptides were selected based on their HPEPDOCK docking energy score, number of binding sites, number and position of selected target residue binding, physiochemical properties, and AVPpred prediction ${ }^{13}$. More negative binding energy and the number and position of residue binding sites were given more importance in selecting the final peptides (described in Results).

\section{Strategy II}

In the second strategy, we screened the available anti-microbial peptides (AMPs) against the SARS-CoV-2 Spike RBD. We used the database of antiviral peptides (AVPdb) ${ }^{19}$, database of HIV inhibitory peptides (HIPdb) ${ }^{12}$, Antimicrobial Peptide Database $(\text { APD } 3)^{20}$, database of anti-microbial peptides (dbAMP) $)^{21}$, and database of FDA-approved peptide and protein therapeutics (THPdb) ${ }^{22}$ and screened the peptides against the SARSCoV-2 Spike RBD. In this process, we collected all the AMP sequences from these databases and then each peptide was docked against the Spike-RBD using the HPEPDOCK protein-peptide docking server ${ }^{18}$. The process and the parameters of HPEPDOCK docking and selection of peptides were the same as used in first strategy.

\section{Strategy III}

In the third strategy, we adopted a chimeric peptide design approach where the two fragments of two different peptides selected in our previous two approaches are composed in such a way that the resultant peptide can bind to our given target residues in the SARS-CoV-2 Spike RBD. In this approach, we first selected the peptides that bind to any of the three key residues (Phe486, Gln493, and Asn501) of the Spike RBD. Next, 
we took various lengths of fragments of these peptides (4-15) that interact with the key residues of Spike RBD. Next, we joined these peptides keeping the key residue position fixed to make chimeric peptides of 20-25 amino acids in length. In these peptides, various permutations and combinations of amino acids were made, keeping the key interacting amino acids and their positions fixed. A total of 500 such chimeric peptides were designed and docked with Spike RBD target residues (Lys417, Tyr453, Gln474, Phe486, Gln493, Gln498, Thr500, and Asn501) using the HPEPDOCK server ${ }^{18}$ as described in the first strategy. The final peptides were selected based on similar criteria as adopted in the first and second strategy.

\section{Physiochemical analysis of peptides}

Antiviral properties of the peptides were predicted using AVPpred $^{13}$ using its default parameters. The molecular formula, molecular weight, net charge, grand average hydropathy, total hydrophobic ratio, hydrophobicity, and protein-binding potential (Boman index) were calculated using the APD3 antimicrobial peptide calculator and predictor ${ }^{20}$. The $\mathrm{IC}_{50}$ of the peptides was predicted using the $\mathrm{AVP}-\mathrm{IC}_{50}$ Pred server, selecting the RSV/INFV/ HSV prediction model ${ }^{23}$ and other default parameters. Hemolytic potency of peptides was determined using the HemoPI server ${ }^{24}$ with default parameters, where the values tending towards " 0 " are unlikely to be hemolytic. ToxinPred ${ }^{25}$, with default parameters, was used to predict the toxicity (toxic or nontoxic) of the peptides. The final peptides were selected based on their: HPEPDOCK docking energy score (cut-off -120 or less), number of $\mathrm{H}$ bonds $(>2)$, number of selected target residue bonds (2-10), number of key target residue bonds $(>2)$, physiochemical properties (parameters acceptable for AMPs, see Extended data $^{26}$ ), and AVPpred prediction (Yes) ${ }^{13}$.

\section{Results and Discussion}

Identification of hACE2 residue-based peptides

In SARS-CoV-2 Spike RBD - hACE2 interaction analysis, similar to Yan et al. $(2020)^{9}$, we found that three stretches of peptides that harbour the active residues of hACE2 interact with Spike RBD. These stretches have amino acid positions: 21-43 (five sites), 78-87 (one site), and 348-361 (two sites). In the Spike RBD, the key interacting amino acid stretches are 480-489 and 490-505. A previous report suggests that among the Spike residues, the most important residues interacting with hACE2 are Phe486, Gln493, and Asn501 ${ }^{27}$. An in-depth analysis revealed that any peptide that potentially blocks the Spike RBD should bind at least three critical positions of the RBD: (i) Gly485 or Phe486 or Asn487, (ii) Gln493, and (iii) Gln498 or Thr500 or Asn501 among which the Phe486, Gln493, and Asn501 are essential.

We designed three peptides from the first stretch of the hACE2 that shows maximum active binding residues with the Spike RBD. A 26 amino acid peptide (AC26) binds to Thr500 and Asn501 of the Spike RBD (Figure 1A), a 23 amino acid peptide (AC23) binds to Tyr489 and Thr500 of the Spike RBD (Figure 1B), and a third 20 amino acid peptide (AC20) binds to Gln493 and Asn501 of the Spike RBD (Figure 1C). All these peptides show acceptable physiochemical properties to be used as therapeutic peptides (see Extended data $^{26}$ ). However, none of these

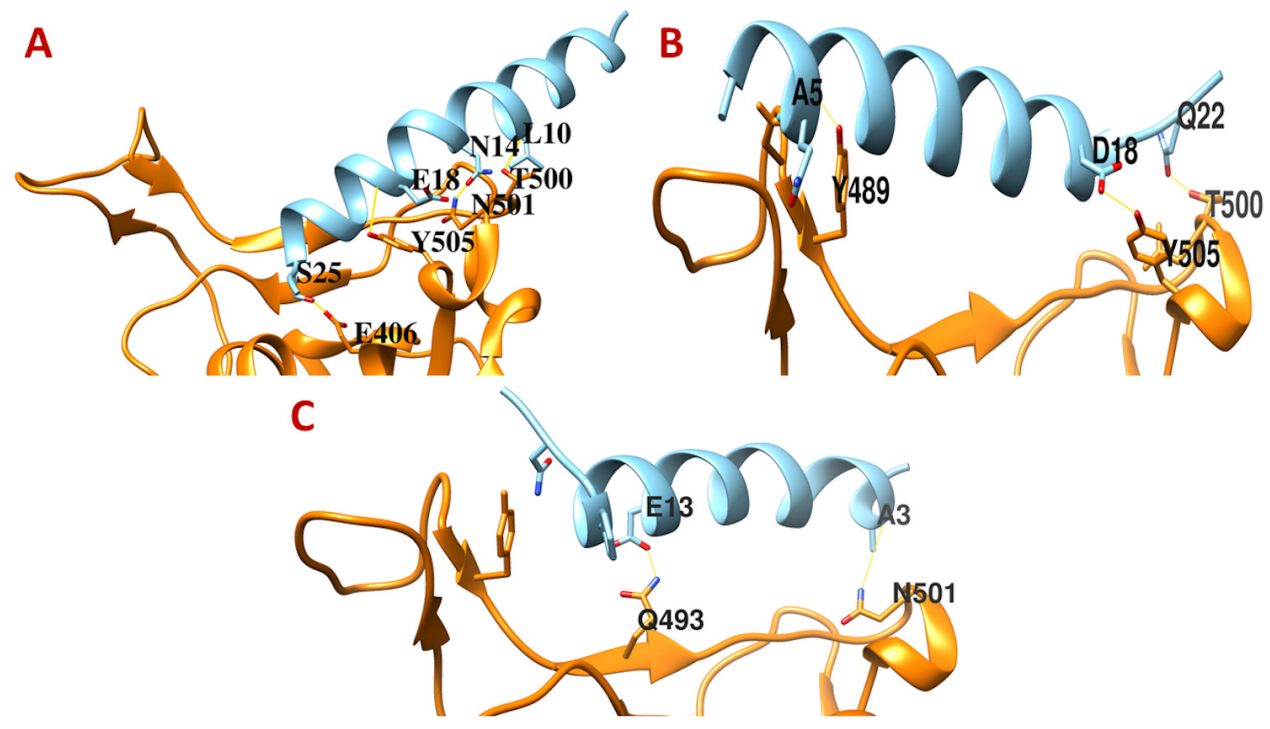

Figure 1. The binding interfaces between SARS-CoV-2 Spike receptor-binding domain with hACE2 derived peptides. (A) AC26, (B) AC23, and (C) AC20. 
three peptides are able to block all the key three positions of the Spike RBD. Therefore, these peptides may not be suitable for developing very effective anti-SARS-CoV-2 therapeutics targeting its Spike RBD. However, AC20 and AC23 can be further tested.

Identification of peptides from antimicrobial peptide databases

We identified seven peptides by screening the five different AMP databases. It is known that SARS-CoV directly interacts with hACE2 through their RBD located in the B chain of the Spike $\operatorname{protein}^{27,29}$ and the Spike protein sequence of SARS-CoV-2 is highly similar to SARS-CoV ${ }^{8}$ and SARS-related coronaviruses. In our peptide database analysis, we also observed that the peptides that have been experimentally proven to be effective against SARS-CoV have the potential of being used against the SARS-CoV-2 Spike protein. All of the seven identified peptides (see Extended data $^{26}$ ) are of 20 amino acids in length and are reported to target the Spike protein of SARS-CoV to exhibit their anti-SARS virus activities ${ }^{19}$. Although the peptides show four to 11 " $\mathrm{H}$ " bonds and form between two to four bonds with our eight given target residues, most of these peptides do not bind to all the three positions ((i) Gly485 or Phe486 or Asn487, (ii) Gln493, and (iii) Gln498 or Thr500 or Asn501) to effectively block the Spike RBD.

The DBP1, DBP2, and DBP3 peptides bind to only the third position (Gln498 and Asn501) of the Spike RBD without binding to the other two sites (Figure 2A-C; Extended data ${ }^{26}$ ). DBP4, DBP5, and DBP7 interact with the first (Gly485 or Phe486 or Asn487) and third (Gln498 and Asn501) sites of the Spike RBD without binding to the middle or the second site (Gln493) (Figure 2D, E, G; Extended data ${ }^{26}$ ). DBP6 binds to all the three sites within the range of the target residues but does not interact with the key residues of the first and third sites (Figure 2F; Extended $\left.d a t a^{26}\right)$. DBP6 is also predicted to be an antiviral peptide by AVPpred ${ }^{13}$. Therefore, DBP6 could be a potential peptide to be tested for SARS-CoV-2 Spike protein-based drug development.

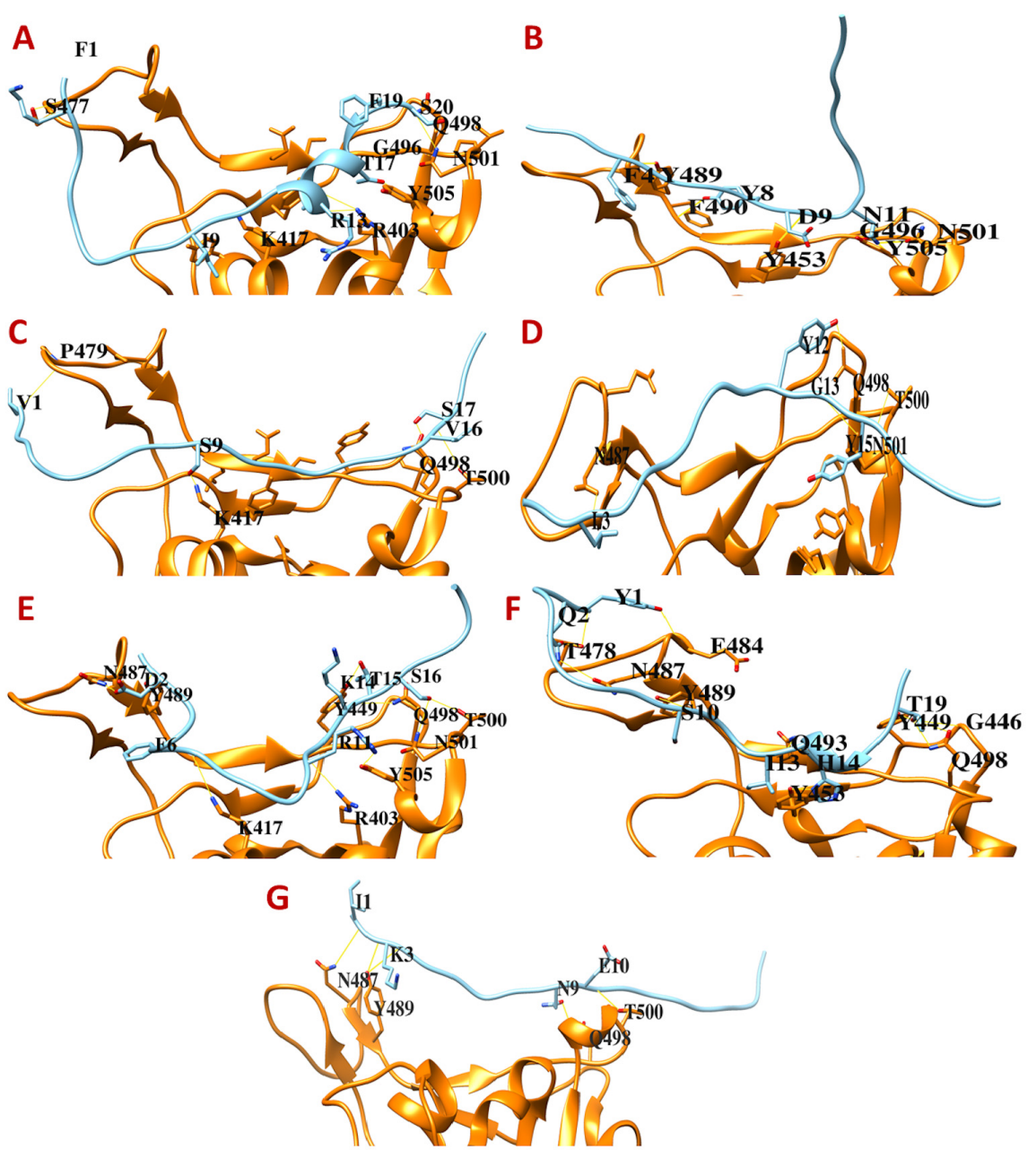

Figure 2. The binding interfaces between SARS-CoV-2 Spike receptor-binding domain with peptides screened from the antimicrobial peptide databases. (A) DBP1, (B) DBP2, (C) DBP3, (D) DBP4, (E) DBP5, (F) DBP6, and (G) DBP7. 
Chimeric peptides against SARS-CoV-2 Spike RBD

Out of 500 chimeric peptides generated, only seven were selected for final analysis. All these peptides are non-hemolytic, non-toxic, and meet all the criteria of a therapeutic peptide (see Extended dat $\left.^{26}\right)$. Among these seven peptides, cnCoVP-3, cnCoVP-4, and cnCoVP-7 interact with all the three sites and two key residues of the second (Gln493) and third (Asn501) sites. However, these peptides bind one amino acid apart from the key residue (Phe486) in the first site and potentially block the access of SARS-CoV-2 Spike Phe486 to the hACE2 (Figure 3C, D, G; Extended data $\left.^{26}\right)$. AVPpred ${ }^{13}$ also predicted cnCoVP-4 to be an antiviral peptide. Therefore, these three peptides could be selected for further in vitro and in vivo testing.

Although the chimeric peptides cnCoVP-2, cnCoVP-5, and cnCoVP-6 interact with all the three sites, they do not interact with the key residue (Phe486) or the immediate to key residue of the first site. Instead they bind a residue that is two to three amino acids apart from the key residue (Phe486) (Figure 3B, E, F;
Extended data $\left.^{26}\right)$. Therefore, these three peptides may not block the first site of the Spike RBD in interacting with hACE2. However, they should also be synthesized and tested for their in vitro effects. The last peptide, cnCoVP-1, was found to interact with all the three sites; however, it only interacts with the key residue $(\mathrm{G} \ln 493)$ of the second site. In the other two sites, it interacts at position (Tyr489) of the first site and (Gln498) of the third site (Figure 3A; Extended data ${ }^{26}$ ). Although Gln498 is a key residue of the third site Tyr489, it is not an interacting residue in the original interaction between SARS-CoV-2 Spike RBD and hACE2. Thus, this peptide may partially block the access of SARS-CoV-2 Spike RBD to hACE2 and needs further in vitro and in vivo testing and validation.

\section{Conclusions}

In this article, we screened and designed several peptides that may potentially block the interaction between SARS-CoV-2 Spike RBD and hACE2. Ten peptides (AC20, AC23, DBP6, and cnCoVP-1- cnCoVP-7) have very high potential to achieve this
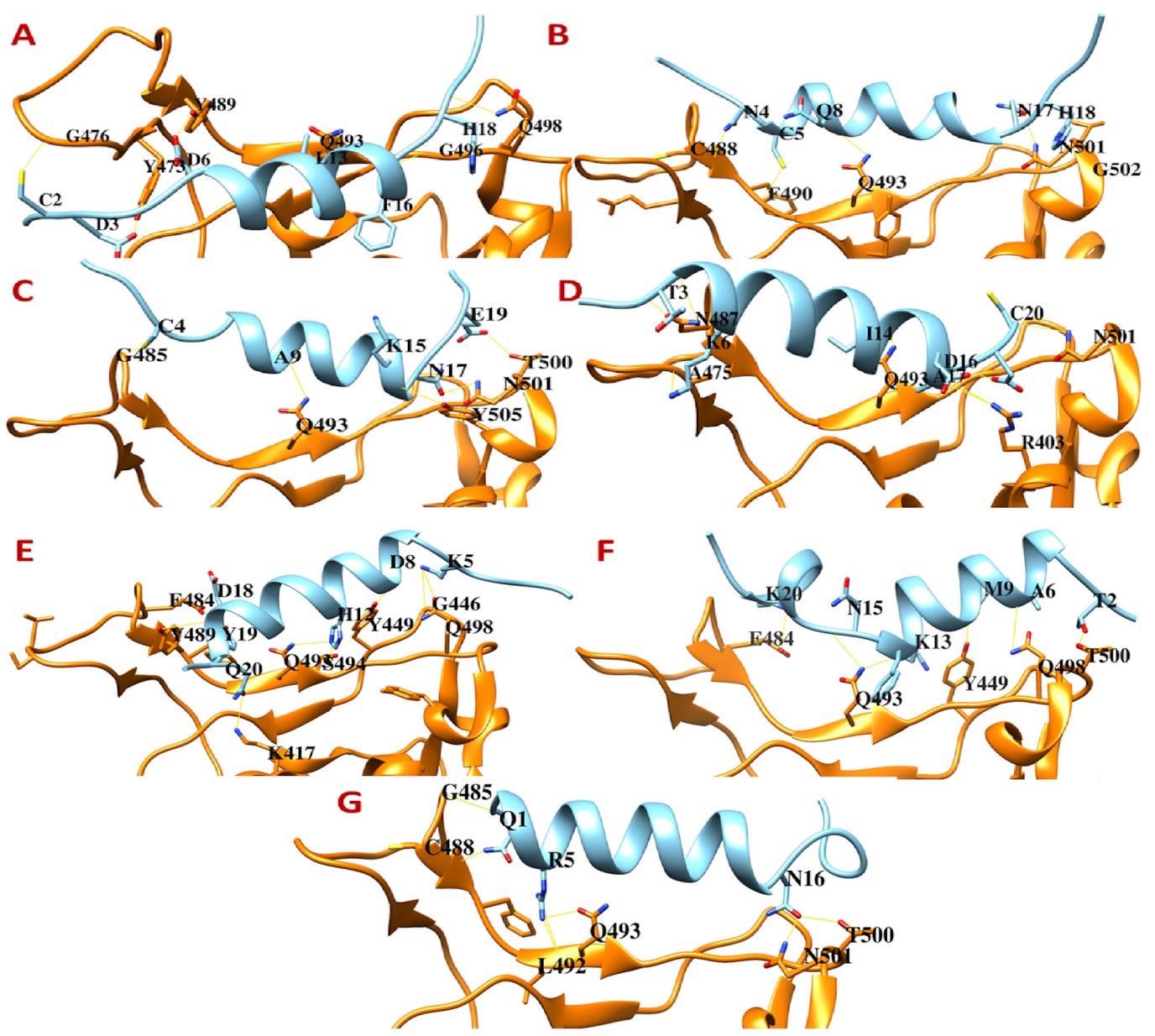

Figure 3. The binding interfaces between SARS-CoV-2 Spike receptor-binding domain with designed chimeric peptides. (A) cnCoVP-1, (B) cnCoVP-2, (C) cnCoVP-3, (D) cnCoVP-4, (E) cnCoVP-5, (F) cnCoVP-6, and (G) cnCoVP-7. 
interaction, indicating that these peptides could be attractive therapeutics against SARS-CoV-2. However, peptide synthesis, in vitro, and in vivo experiments are required to evaluate and ensure their potential therapeutic efficacy.

\section{Data availability}

Source data

B chain of SARS-CoV-2 Spike RBD from PDB, Accession number 6LZG: https://identifiers.org/rcsb/pdb:6LZG

B chain of hACE2 from PDB, Accession number 6M18: https:// identifiers.org/rcsb/pdb:6M18

\section{Extended data}

Harvard Dataverse: Potential chimeric peptides to block the SARSCoV-2 Spike RBD. https://doi.org/10.7910/DVN/WSDRTU ${ }^{26}$

This project contains the following extended data:

- MS_cnCoVP_Supplementary_Table-S1_F1000.x1sx (detailed physiochemical and docking properties and AVPpred prediction of each peptide)

Data are available under the terms of the Creative Commons Zero "No rights reserved" data waiver (CC0 1.0 Public domain dedication)
1. Chen N, Zhou M, Dong X et al: Epidemiological and clinical characteristics of 99 cases of 2019 novel coronavirus pneumonia in wuhan, china: A descriptive study. Lancet. 2020; 395(10223): 507-513.

PubMed Abstract | Publisher Full Text | Free Full Text

2. Huang C, Wang Y, Li X, et al.: Clinical features of patients infected with 2019 novel coronavirus in wuhan, china. Lancet. 2020; 395(10223): 497-506. PubMed Abstract | Publisher Full Text | Free Full Text

3. Liu NN, Tan JC, Li J, et al.: Covid-19 pandemic: Experiences in china and implications for its prevention and treatment worldwide. Curr Cancer Drug Targets. 2020; 20.

PubMed Abstract | Publisher Full Text

4. Singh AK, Singh A, Shaikh A, et al:: Chloroquine and hydroxychloroquine in the treatment of covid-19 with or without diabetes: A systematic search and a narrative review with a special reference to india and other developing countries. Diabetes Metab Syndr. 2020; 14(3): 241-246. PubMed Abstract | Publisher Full Text | Free Full Text

5. Zhou $P$, Yang $X L$, Wang $X G$, et al:: A pneumonia outbreak associated with a new coronavirus of probable bat origin. Nature. 2020; 579(7798): 270-273. PubMed Abstract | Publisher Full Text | Free Full Text

6. Moore MJ, Dorfman T, Li W, et al:: Retroviruses pseudotyped with the severe acute respiratory syndrome coronavirus Spike protein efficiently infect cells expressing angiotensin-converting enzyme 2. J Virol. 2004; 78(19): 1062810635 .

PubMed Abstract | Publisher Full Text | Free Full Text

7. Hoffmann M, Kleine-Weber H, Schroeder S, et al:: Sars-cov-2 cell entry depends on ace 2 and tmprss 2 and is blocked by a clinically proven protease inhibitor. Cell. 2020; 181(2): 271-280.e8.

PubMed Abstract | Publisher Full Text | Free Full Text

8. Walls AC, Park YJ, Tortorici MA, et al:: Structure, function, and antigenicity of the sars-cov-2 Spike glycoprotein. Cell. 2020; 181(2): 281-292.e6. PubMed Abstract | Publisher Full Text | Free Full Text

9. Yan R, Zhang Y, Li Y, et al:: Structural basis for the recognition of sars-cov-2 by full-length human ace2. Science. 2020; 367(6485): 1444-1448. PubMed Abstract | Publisher Full Text | Free Full Text

10. Castel G, Chteoui M, Heyd B, et al:: Phage display of combinatorial peptide libraries: Application to antiviral research. Molecules. 2011; 16(5): 3499-3518. PubMed Abstract | Publisher Full Text | Free Full Text

11. Mujtaba MG, Patel CB, Patel RA, et al:: The gamma interferon (ifn-gamma) mimetic peptide ifn-gamma (95-133) prevents encephalomyocarditis virus infection both in tissue culture and in mice. Clin Vaccine Immunol. 2006; 13(8): 944-952.

PubMed Abstract | Publisher Full Text | Free Full Text

12. Qureshi A, Thakur N, Kumar M: Hipdb: A database of experimentally validated hiv inhibiting peptides. PLOS One. 2013; 8(1): e54908. PubMed Abstract | Publisher Full Text | Free Full Text

13. Thakur N, Qureshi A, Kumar M: Avppred: Collection and prediction of highly effective antiviral peptides. Nucleic Acids Res. 2012; 40: W199-204. PubMed Abstract | Publisher Full Text | Free Full Text

14. Liu IJ, Kao CL, Hsieh SC, et al.: Identification of a minimal peptide derived from heptad repeat (hr) 2 of Spike protein of sars-cov and combination of hr1derived peptides as fusion inhibitors. Antiviral Res. 2009; 81(1): 82-87. PubMed Abstract | Publisher Full Text | Free Full Text

15. Ujike $M$, Nishikawa $H$, Otaka A, et al.: Heptad repeat-derived peptides block protease-mediated direct entry from the cell surface of severe acute respiratory syndrome coronavirus but not entry via the endosomal pathway. $J$ Virol. 2008; 82(1): 588-592.

PubMed Abstract | Publisher Full Text | Free Full Text

16. Chu LH, Chan SH, Tsai SN, et al:: Fusion core structure of the severe acute respiratory syndrome coronavirus (sars-cov): In search of potent sars-cov entry inhibitors. J Cell Biochem. 2008; 104(6): 2335-2347. PubMed Abstract | Publisher Full Text | Free Full Text

17. van Zundert GCP, Rodrigues JPGLM, Trellet M, et al.: The HADDOCK2.2 Web Server: User-Friendly Integrative Modeling of Biomolecular Complexes. $J \mathrm{Mol}$ Biol. 2016; 428(4): 720-725.

PubMed Abstract | Publisher Full Text

18. Zhou P, Jin B, Li H, et al:: Hpepdock: A web server for blind peptide-protein docking based on a hierarchical algorithm. Nucleic Acids Res. 2018; 46(W1): W443-W450.

PubMed Abstract | Publisher Full Text | Free Full Text

19. Qureshi A, Thakur N, Tandon H, et al:: Avpdb: A database of experimentally validated antiviral peptides targeting medically important viruses. Nucleic Acids Res. 2014; 42: D1147-1153. PubMed Abstract | Publisher Full Text | Free Full Text

20. Wang G, Li X, Wang Z: Apd3: The antimicrobial peptide database as a tool for research and education. Nucleic Acids Res. 2016; 44(D1): D1087-1093. PubMed Abstract | Publisher Full Text | Free Full Text

21. Jhong JH, Chi YH, Li WC, et al.: dbAMP: An Integrated Resource for Exploring Antimicrobial Peptides With Functional Activities and Physicochemical Properties on Transcriptome and Proteome Data. Nucleic Acids Res. 2019; 47(D1): D285-D297.

PubMed Abstract | Publisher Full Text | Free Full Text

22. Usmani SS, Bedi G, Samuel JS, et al.: Thpdb: Database of fda-approved peptide and protein therapeutics. PLOS One. 2017; 12(7): e0181748.

PubMed Abstract | Publisher Full Text | Free Full Text

23. Qureshi A, Tandon H, Kumar M: AVP-IC ${ }_{50}$ Pred: Multiple Machine Learning Techniques-Based Prediction of Peptide Antiviral Activity in Terms of Half Maximal Inhibitory Concentration (IC ${ }_{50}$ ). Biopolymers. 2015; 104(6): 753-763. PubMed Abstract | Publisher Full Text | Free Full Text

24. Chaudhary K, Kumar R, Singh S, et al:: A Web Server and Mobile App for Computing Hemolytic Potency of Peptides. Sci Rep. 2016; 6: 22843. PubMed Abstract | Publisher Full Text | Free Full Text

25. Gupta S, Kapoor P, Chaudhary K, et al.: In Silico Approach for Predicting Toxicity of Peptides and Proteins. PLoS One. 2013; 8(9): e73957. PubMed Abstract | Publisher Full Text | Free Full Text

26. Barh D: Potential chimeric peptides to block the SARS-CoV-2 Spike RBD Harvard Dataverse, V1.2020. http://www.doi.org/10.7910/DVN/WSDRTU

27. Chen $Y$, Guo Y, Pan Y, et al:: Structure Analysis of the Receptor Binding of 2019-nCoV. Biochem Biophys Res Commun. 2020; 525(1): 135-140. PubMed Abstract | Publisher Full Text | Free Full Text

28. Ge XY, Li JL, Yang XL, et al.: Isolation and Characterization of a Bat SARS-like Coronavirus That Uses the ACE2 Receptor. Nature. 2013; 503(7477): 535-538.

PubMed Abstract | Publisher Full Text | Free Full Text

29. Song W, Gui M, Wang X, et al.: Cryo-em structure of the sars coronavirus Spike glycoprotein in complex with its host cell receptor ace2. PLoS Pathog. 2018 14(8): e1007236.

PubMed Abstract | Publisher Full Text | Free Full Text 


\section{Open Peer Review}

\section{Current Peer Review Status:}

\section{Version 1}

Reviewer Report 24 August 2020

https://doi.org/10.5256/f1000research.26557.r68734

(C) 2020 Ali A. This is an open access peer review report distributed under the terms of the Creative Commons Attribution License, which permits unrestricted use, distribution, and reproduction in any medium, provided the original work is properly cited.

\section{Amjad Ali}

Atta-ur-Rahman School of Applied Biosciences (ASAB), National University of Sciences and Technology (NUST), Islamabad, Pakistan

The study manuscript "Potential chimeric peptides to block the SARS-CoV-2 spike receptor-binding domain" by Barh et al., focuses on chimeric peptides to potentially block the SARS-CoV-2 receptor binding domain; the work is interesting and well designed and written. I have few minor comments and suggestions if they could be considered by the authors for improvement and clarification.

As mentioned "SARS-CoV binds to the human angiotensin-converting enzyme 2 (hACE2) receptor through its Spike protein (S) to enter into the host cell ${ }^{6}$, and it is now reported that SARS-CoV-2 also binds to ACE2 to transmit its genetic material to human cells $s^{7-9 "}$

In these lines the authors stated that SARS-CoV-2 also binds to ACE2, I think the authors intended to write hACE2 (as stated earlier). The abbreviation is inconsistent in the whole manuscript. Please have a look.

Comment: The authors stated that AVP are a better choice in catering viral infection, but as they are peptides, they are prone to be attacked by proteases. How to overcome this issue?

Comment: Do these AVPs have a role in generating memory response? If the AVPs directly evoke innate immune response there is a possibility the PAMPs present on these can be recognized by PRRs which may lead to degradation.

Comment: A study similar to Strategy 1 has been conducted by Ibrahim et al. $\left(2020^{1}\right)$ to predict binding residues between RBD and hACE2. Does your study validate those findings? Are there any differences?

Comment: Which tool or database was used to design AVPs in strategy 1?

Comment: As the authors discussed the hemolytic potential of chimeric peptides, were peptides designed using Strategy 1 and Strategy 2 also fulfilling the criteria of therapeutic potential? Also, 
among the ten peptides mentioned in the conclusion which of them are best? Is it possible to give a brief comparison of these 10 peptides?

\section{References}

1. Ibrahim IM, Abdelmalek DH, Elshahat ME, Elfiky AA: COVID-19 spike-host cell receptor GRP78 binding site prediction.J Infect. 80 (5): 554-562 PubMed Abstract | Publisher Full Text

Is the work clearly and accurately presented and does it cite the current literature? Yes

Is the study design appropriate and is the work technically sound? Yes

Are sufficient details of methods and analysis provided to allow replication by others? Partly

If applicable, is the statistical analysis and its interpretation appropriate? Not applicable

Are all the source data underlying the results available to ensure full reproducibility? Partly

Are the conclusions drawn adequately supported by the results? Yes

Competing Interests: No competing interests were disclosed.

I confirm that I have read this submission and believe that I have an appropriate level of expertise to confirm that it is of an acceptable scientific standard, however I have significant reservations, as outlined above.

Reviewer Report 06 August 2020

https://doi.org/10.5256/f1000research.26557.r68731

(C) 2020 Dwivedi S. This is an open access peer review report distributed under the terms of the Creative Commons Attribution License, which permits unrestricted use, distribution, and reproduction in any medium, provided the original work is properly cited.

\section{Shailendra Dwivedi}

Department of Biochemistry, All India Institute of Medical Sciences, Gorakhpur, Uttar Pradesh, India

The overall article is well written and has properly compiled the report on "Potential chimeric peptides to block the SARS-CoV-2 spike receptor-binding domain" which is oriented on the present pandemic of COVID-19. The authors have screened and designed many peptides that can 
potentially block the interaction between SARS-CoV-2 Spike RBD and hACE2. Thus, the authors concluded that ten peptides (AC20, AC23, DBP6, and cnCoVP-1- cnCoVP-7) have a very high potential of interaction, indicating that these peptides could be attractive therapeutics against SARS-CoV-2.

The authors have used proper methodologies to conclude the report, so it can be accepted for indexing.

Is the work clearly and accurately presented and does it cite the current literature? Yes

Is the study design appropriate and is the work technically sound? Yes

Are sufficient details of methods and analysis provided to allow replication by others? Yes

If applicable, is the statistical analysis and its interpretation appropriate? Yes

Are all the source data underlying the results available to ensure full reproducibility? Yes

Are the conclusions drawn adequately supported by the results? Yes

Competing Interests: No competing interests were disclosed.

Reviewer Expertise: Molecular Biology, Cancer Stem Cell, Epigenetics, Nutrigenomics, Cancer Biology

I confirm that I have read this submission and believe that I have an appropriate level of expertise to confirm that it is of an acceptable scientific standard.

Reviewer Report 29 June 2020

https://doi.org/10.5256/f1000research.26557.r64504

(C) 2020 Hizel C. This is an open access peer review report distributed under the terms of the Creative Commons Attribution License, which permits unrestricted use, distribution, and reproduction in any medium, provided the original work is properly cited.

\section{Candan Hizel}

OPTI-THERA Inc./Medpharmgene, Montreal, QC, Canada

The coronavirus disease 2019 (COVID-19) pandemic has created a worldwide crisis and inspired an 
urgent search for prevention and treatment of severe acute respiratory syndrome coronavirus 2 (SARS-CoV-2) infection.

Barh and his colleagues describe in this article the important role of immuno-informatics by using molecular modeling and docking for chimeric peptide design anti-Spike peptides for SARS-CoV-2 potential therapeutics against the covid-19 infection. The introduction provides a good, generalized background of the topic that quickly gives the reader an appreciation of the applications of the technique. "A large global effort is required to stop viral epidemics and pandemics, and these manuscript insights may lead to identifying novel ways to stop infection." To this end, this manuscript highlights clearly the potential opportunities several peptides blocking the interaction between SARS-CoV-2 Spike RBD and hACE2 as probable application in clinical practice.

Overall the topic and the data are very interesting. The manuscript is very well written, well organized, easy to follow, and appropriate in scope and method. Certainly this study will contribute much to the literature.

Is the work clearly and accurately presented and does it cite the current literature? Yes

Is the study design appropriate and is the work technically sound? Yes

Are sufficient details of methods and analysis provided to allow replication by others? Yes

If applicable, is the statistical analysis and its interpretation appropriate? Yes

Are all the source data underlying the results available to ensure full reproducibility? Yes

Are the conclusions drawn adequately supported by the results? Yes

Competing Interests: No competing interests were disclosed.

Reviewer Expertise: Pharmacogenomics

I confirm that I have read this submission and believe that I have an appropriate level of expertise to confirm that it is of an acceptable scientific standard.

Author Response 30 Jun 2020

Debmalya Barh, Institute of Integrative Omics and Applied Biotechnology, Nonakuri, Purba Medinipur, India 
Thank you for your critical review and approval.

Competing Interests: No competing interests were disclosed.

The benefits of publishing with F1000Research:

- Your article is published within days, with no editorial bias

- You can publish traditional articles, null/negative results, case reports, data notes and more

- The peer review process is transparent and collaborative

- Your article is indexed in PubMed after passing peer review

- Dedicated customer support at every stage

For pre-submission enquiries, contact research@f1000.com 